\title{
Development of a Methodology for Activity Pattern Representation for Individuals in Western Province of Sri Lanka
}

\section{P.D.L. Fernando and G.L.D.I. De Silva}

\begin{abstract}
Activity based transport demand models are used to model complex human behavioural responses to policy decisions. Activity pattern formulation is an important aspect of the model development process. The travel demand models developed and used currently in Sri Lanka are the traditional trip-based models. These models, although can be enhanced, have limitation of being unresponsive to disaggregate level changes. With the increasing demand for the models to be more responsive for policy decision and project formulation, there is a need to move towards disaggregate level modelling, thus the need for an activity-based model (ABM). Understanding the activity pattern groups of the study area is a priori and the first step towards building ABM. But, there has not been any previous work for Sri Lanka to understand the activity pattern groups. Therefore, this research develops a method for representation of activity patterns of individuals for Western province of Sri Lanka. The home visit survey (HVS) data collected as part of CoMTrans study done in 2013 has been used. Each member's activity pattern was developed with spatial and temporal representation. 1,106 unique activity patterns were identified with education based and work-based patterns having the highest frequency. These were categorised into three main categories (Education, Work and Other), and each member was assigned a category based on pattern's main trip. These categories were further divided based on number of tours, purpose, diversions and time of travel. The main activity pattern of each subgroup was also identified. Further analysis of the subgroups provided behavioural aspects that are relevant to each tour purpose. The study identified 17 subgroups consisting of 5 work, 4 educational and 8 other pattern groups.
\end{abstract}

Keywords: Activity pattern, Travel behaviour, Activity based modelling, Home visit survey, Spatial-temporal representation

\section{Introduction}

Impacts of transport policies and transport infrastructure are assessed using transport demand models. The conventional trip/tourbased models consider vehicle flows/trips between zones as the unit of analysis. But, with the shift from long term to short term assessment, the model requirements focused towards predicting behavioural responses. The trip/tour-based models fail to capture complex travel and activity patterns that have arisen due to technological, social and behavioural developments [1].

The transport modellers have moved towards activity-based models which capture travel as a derived demand from participating in activities distributed in time and space and consider individual activity patterns as the unit of analysis. A typical activity-based model consists of following features including Population synthesis, Daily activity pattern formulation, Tour formulation, Time of day and mode choice and Network assignment [2] [3]. The travel demand models used currently in Sri
Lanka are trip-based models. With the emphasis of more disaggregate analysis for policy testing and project formulation, there is a need in the near future to move towards activity-based modelling which is a more state of the art modelling method. An important first step towards activity-based model development is identifying the groups of individual activity patterns.

There have been different methods for activity pattern representation done worldwide [8], [9], [10]. However, the activity patterns formulated elsewhere cannot be directly adopted in local context since an individual's activity pattern will depend on individual characteristics (demographics, lifestyle, preferences etc.), built

Eng. P.D.L. Fernando, AMIE(SL), B.Sc. Eng. (Hons) (Moratuwa), Graduate Research Assistant, Department of

Civil Engineering, University of Moratuwa.

Email:198075E@uom.lk

(iD http://orcid.org/0000-0001-9131-2381

Dr. G.L.D.I. De Silva, B.Sc. Eng. (Hons) (Moratuwa), M.Sc. (Moratuwa), Ph.D. (Calgary), P.Eng. (Alberta),

Senior Lecturer, Department of Civil Engineering,

University of Moratuwa.

(iD https://orcid.org/0000-0001-9113-4773 
environment (land use patterns, transportation systems etc.) and social environment (Society values, public policies, economic factors etc.) [16]. Hence a suitable method to represent activity patterns in local context is important. But there has not been any previous work for Sri Lanka to understand or identify the activity pattern groups representative of local context.

Therefore, the objective of the research is to develop a method for representation of activity patterns of individuals in Western Province of Sri Lanka based on the household survey data.

\section{Literature Review}

\subsection{Activity Pattern Generation}

Representative activity patterns, which can be defined as grouping of similar activity patterns, can be considered as the base for an activity pattern generation model [4]. Activity patterns that are subjected to daily variations can be identified by classifying them into several pattern types [5], [6]. Prediction of an individual's activity pattern can be carried out using the relationship between socioeconomic characteristics of an individual and his/her daily activity pattern which requires specification of activity patterns prior to clustering them using socioeconomic characteristics [4], [7].

\subsection{Activity Pattern Representation}

Specification of activity patterns requires representation of time and space dimensions. Space dimension consists of both travel and spatial representation.

\section{Time/Frequency Representation}

Time/frequency can be represented by using the number of stops to capture the effect of temporal dimension [8].

Time can also be represented by dividing the time of day to representative time categories based on peak and off peak times such as Early Off-peak (3am-6am), AM Peak (6am-10am), Midday (10am-3pm), PM Peak (3pm-7pm) and Late Off-peak (7pm-3am) [9]. Time periods defined by Galgamuwa et al. [10] can be used to develop a similar time period categorization for the Sri Lankan context.

\section{Travel Representation}

Travel representation can be carried out by assuming travel being represented by change in location where the developed model will be simpler [9].
Travel can also be represented as a separate activity which enables future updating of congested travel times [11].

\section{Spatial Representation}

A simpler activity pattern with relatively less computational times can be developed by not specifying a code for spatial representation in an individual's activity pattern. It is assumed that the code for an activity will inherently include the spatial representation for that activity [9].

Another method for spatial representation is the use of coded locations (i.e., home, work, leisure and other). This results in a more accurate activity pattern representation but at the expense of increase in complexity and computational times [12].

The actual coordinates of the activity can also be used for spatial representation by defining an individual's location based on northing, easting and zenith $(x, y, z)$. This is the most accurate representation of an individual's activity pattern in terms of spatial representation. But, with the increase of the sample size, the complexity of patterns and computational times will increase significantly [13].

\section{Home Visit Survey Data}

The research objective of identifying activity patterns requires individual activity/travel details with respect to space (origin and destination) and time (arrival and departure times) dimensions. The above information is usually collected as part of travel diaries or Home Visit Surveys. The Home Visit Survey (HVS) conducted during the CoMTrans study in 2013, which is currently the largest and comprehensive personal travel survey carried out in Western Province of Sri Lanka, was used for the study. The data has also been extensively used for transport demand modelling in the country [14].

The HVS collected information relates to travel activities of residents and their respective socioeconomic characteristics. The travel activities include details relating to an individual's trips such as origin, departure time, arrival time, destination, mode, some mode characteristics (i.e. waiting time, ride time, fare etc.). 
The target sample size of the HVS survey was $3 \%$ of the population of Western Province with the final processed dataset including data related to 35,850 households. The HVS dataset contains about 10 million trips. Obtained information was restricted to members of the age of 5 years and above in households. Random sampling technique had been used for selection of the sample [14].

Comparison of age distribution for HVS data and 2012 census data [15] for Western province is shown in Figure 1. Based on the age distribution, $35 \%$ of the individuals are under 20 years which is expected to represent education patterns predominantly, and $58 \%$ are of the 20 to 60 years age group which is expected to be the main contributor for work and other patterns. Hence, each of the main activity purposes are significantly represented in the sample dataset. Figure 1 also indicates that the selected HVS dataset is representative of the population. Therefore, the HVS dataset was used instead of primary data collection, due to its suitability with respect to the research objectives.

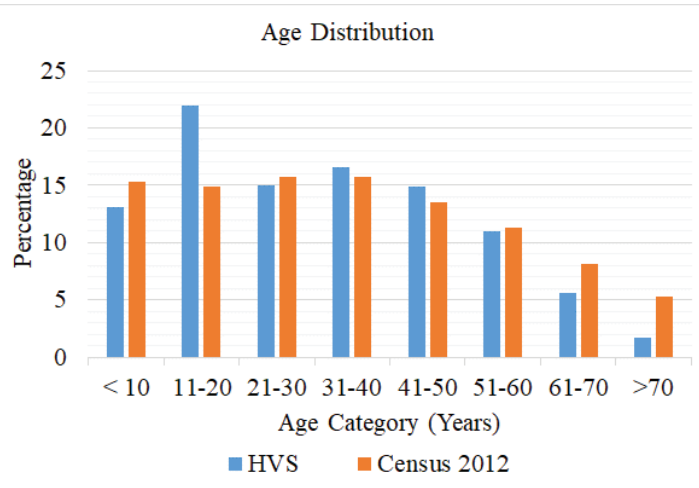

Figure 1 - Age Distribution

\section{Activity Patterns}

\subsection{Activity Pattern Development}

Based on the characteristics of the available travel data, it was identified that the most suitable method for activity pattern representation was the usage of only space and time dimensions.

The following codes based on the origin and destination of the trip were used for spatial representation.

- Home - H

- Workplace - W

- School/Education Institute - S

- Other - O
The coding used for temporal representation based on the departure time period of the trip is indicated in Table 1.

Table 1 - Temporal Representation Codes

\begin{tabular}{|l|l|c|}
\hline \multicolumn{1}{|c|}{$\begin{array}{c}\text { Time } \\
\text { Period }\end{array}$} & \multicolumn{1}{|c|}{ Description } & Code \\
\hline $0: 00-5: 59$ & $\begin{array}{l}\text { EARLY OFF } \\
\text { PEAK }\end{array}$ & 1 \\
\hline $6: 00-9: 59$ & AM PEAK & 2 \\
\hline $10: 00-14: 59$ & MIDDAY & 3 \\
\hline $15: 00-18: 59$ & PM PEAK & 4 \\
\hline $19: 00-23: 59$ & $\begin{array}{l}\text { LATE OFF } \\
\text { PEAK }\end{array}$ & 5 \\
\hline
\end{tabular}

A person leaving home at 6:15am to go to the workplace and departing from workplace at 17:00 to return home can be represented by an activity pattern based on the above coding systems considering two trips. The trip to work can be represented as "H2W" and the return trip back from work to home can be represented as "W4H". By combining the trips, the individual's daily activity pattern can be represented as " $\mathrm{H} 2 \mathrm{~W} 4 \mathrm{H}$ ".

By adopting the above method, it was found that the dataset contained 1,106 such unique activity patterns.

\subsection{Activity Pattern Adjustments Data Cleaning}

The following types of patterns were classified as incorrect patterns and were removed.

- Patterns consisting of only 1 trip with no return home trip (i.e. $\mathrm{H} 2 \mathrm{~W}$ )

- Patterns starting location not being Home (i.e. O2W4O)

- Patterns consisting of incorrect travel data (i.e. H2S1H - Wrong departure times)

2,661 out of 78,953 members were identified as members with incorrect activity patterns and were removed from further analysis.

\section{Tour completeness}

The completeness of each tour was determined by comparing the similarity of the starting and ending origin types.

e.g.

- "H2W4H" is a complete tour as both the starting and ending origin types $(\mathrm{H})$ are the same

- " $\mathrm{H} 2 \mathrm{O} 2 \mathrm{~W}$ " is an incomplete tour as starting (i.e., " $\mathrm{H}^{\prime}$ ) and ending (i.e., "W") origin types aren't similar

51 members were identified as individuals with incomplete patterns and were removed. 


\subsection{Tour Purpose}

All members were assigned a tour purpose (Work, Educational, Other) based on trip purpose as follows.

- To work trips - Work tour purpose

- To school trips - Educational tour purpose

- Shopping, business, private matters, other trips - Other tour purpose

In cases where there were multiple tours, most prominent purpose was assigned as the tour purpose. For the extracted complete tours, the tour purpose distribution is shown in Figure 2.

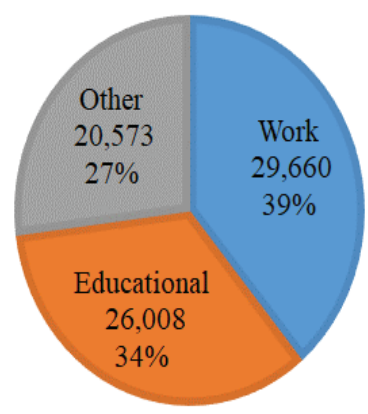

Figure 2 - Tour Purpose Distribution

The most frequent tour purpose can be identified as work tours which is followed by educational and other purposes. The distribution is in line with age distribution of the dataset with the highest percentage of expected working age group's (i.e. 20-60 years) influence and the next highest percentage of school age group's (i.e. 0-20 years) influence both being reflected with tour purpose distributions of work and educational purposes, respectively.

\subsection{Activity Pattern Results}

Activity patterns with more than $1 \%$ representation is shown in Table 2.

The highest represented pattern is an educational purpose pattern. But based on tour purpose distribution work, purpose patterns (38.9\%) were more than educational purpose patterns $(34.1 \%)$. This apparent discrepancy can be explained when unique activity patterns related to each tour purpose group is understood. The highest frequent pattern of " $\mathrm{H} 2 \mathrm{~S}_{3} \mathrm{H}^{\prime}$ is where the member leaves home in the AM peak to school/education institute and returns home during the midday time period. Travel schedule of majority of school students will have this unique activity pattern. But, in the case of work patterns, the departure time from home and arrival time back at home can vary based on factors such as occupation and work category (i.e. full time or part time).

Table 2 - Highest Represented Activity Patterns

\begin{tabular}{|l|c|c|c|}
\hline \multicolumn{1}{|c|}{ Pattern } & $\begin{array}{c}\text { No. of } \\
\text { Members }\end{array}$ & \% & Purpose \\
\hline $\mathrm{H} 2 \mathrm{~S} 3 \mathrm{H}$ & 22,281 & 28.7 & Educational \\
\hline $\mathrm{H} 2 \mathrm{~W} 4 \mathrm{H}$ & 16,322 & 21.0 & Work \\
\hline $\mathrm{H} 2 \mathrm{O} 3 \mathrm{H}$ & 5,105 & 6.6 & Other \\
\hline $\mathrm{H} 2 \mathrm{~W} 5 \mathrm{H}$ & 4,552 & 5.9 & Work \\
\hline $\mathrm{H} 3 \mathrm{O} 3 \mathrm{H}$ & 3,779 & 4.9 & Other \\
\hline $\mathrm{H} 2 \mathrm{O} 4 \mathrm{H}$ & 3,340 & 4.3 & Other \\
\hline $\mathrm{H} 2 \mathrm{~W} 3 \mathrm{H}$ & 2,026 & 2.6 & Work \\
\hline $\mathrm{H} 1 \mathrm{~W} 4 \mathrm{H}$ & 1,645 & 2.1 & Work \\
\hline $\mathrm{H} 2 \mathrm{O} 2 \mathrm{H} 3 \mathrm{O} 3 \mathrm{H}$ & 1,590 & 2.0 & Other \\
\hline $\mathrm{H} 2 \mathrm{O} 2 \mathrm{H}$ & 1,438 & 1.8 & Other \\
\hline $\mathrm{H} 2 \mathrm{~S} 4 \mathrm{H}$ & 1,070 & 1.4 & Educational \\
\hline $\mathrm{H} 4 \mathrm{O} 4 \mathrm{H}$ & 1,193 & 1.5 & Other \\
\hline $\mathrm{H} 3 \mathrm{O} 4 \mathrm{H}$ & 991 & 1.3 & Other \\
\hline
\end{tabular}

This variation is reflected in several different work patterns such as "H2W4H", "H2W5H", "H1W4H" etc where the activity order remains the same but the pattern differentiated by the departure time from home and return from work. Another reason is that most workers will have other purposes (i.e., shopping, banking) also attached to their work trip and hence the activity pattern will change from "HWH" form to "HWOH" form and similar variations. Hence, work purpose tours, though having the highest frequency based on tour purpose, will have comparatively higher number of activity pattern variations when compared to education purpose patterns. Therefore, when unique activity patterns are considered the less varying education purpose pattern will have a higher frequency.

The obtained results also show that work patterns and other purpose patterns vary significantly from individual to individual when compared to education purpose patterns. This behaviour must be considered when deciding to group members based on their activity pattern.

\subsection{Activity Pattern Grouping}

For each tour purpose (i.e. work, educational, other) similar patterns were grouped in the following method.

\section{Work patterns}

All activity patterns with work purpose were grouped based on combination of following factors. 
1. No. of work tours [1 tour(1WT), 1 tour + subtours $(1 \mathrm{WT}+\mathrm{Sub}), 2+$ tours (WT2+)]

2. No. of diversions (0 stops, 1 stop, $2+$ stops)

3. No. of non-work tours $(0,1,2+)$

4. Time categorization:

- For 1 work tour

- Full Time Peak (FT_Peak)

- Full Time Early (FT_Early)

- Full Time Late (FT_Late)

- Part Time Early (PT_Early)

- Part Time Late (PT_Late)

- For 1 work tour + subtours

- Full Time Peak (FT_Peak)

- All Other

- For 2+ work tours - All

In terms of number of work tours " 1 tour + subtours" is where the individual will have a secondary tour (i.e. go out for lunch) attached to the main work tour and the activity pattern will take "HWOWH" and variations of its form. "2+tours" is where the individual will have two work tours (i.e. come home midday and go back to work) and the activity patterns will take "HWHWH" and variations of its form.

Diversions are where the individual will have other locations (i.e. shop, bank) attached to the work tour and the patterns will take " $\mathrm{HWOH}$ and variations based on the number of stop locations.

Non work tours are when an individual will have other tours additionally to the work tour (i.e. go out for dinner after returning home from work) and the activity pattern will take " $\mathrm{HWHOH}$ " and variations of its form.

\section{Table 3 - Work Pattern Time Categorization}

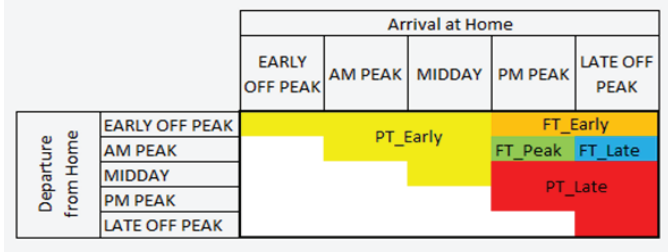

Time categorization is based on the time the individual departs from home and arrives back at home and how each time category is defined is indicated in Table 3. For 1 work tour a higher level of detail is given to time categories and with the addition of subtours and work tours the time categories were simplified.

Table 4 indicates how pattern grouping was carried out using the combination of factors.

Table 5 indicates the frequencies for initially identified 15 work pattern groups. Each pattern group is identified based on "[No. of work tours] @ [Time category] @ [No. of diversions] @ [No. of non-work tours]" code.

Table 5 - Initially Identified Work Pattern Groups

\begin{tabular}{|c|c|c|c|}
\hline Pattern Group & ID & $\begin{array}{c}\text { In } \\
\text { Sample }\end{array}$ & $\%$ \\
\hline $\begin{array}{l}\text { 1WT@FT_Early@0 } \\
\text { Stops@0 }\end{array}$ & 20 & 2,289 & 7.7 \\
\hline $\begin{array}{l}\text { 1WT@FT_Late@0 } \\
\text { Stops @0 }\end{array}$ & 21 & 4,552 & 15.3 \\
\hline $\begin{array}{l}\text { 1WT@FT_Peak@0 } \\
\text { Stops@0 }\end{array}$ & 22 & 16,322 & 55.0 \\
\hline $\begin{array}{l}\text { 1WT@PT_Early@0 } \\
\text { Stops@0 }\end{array}$ & 23 & 2,843 & 9.6 \\
\hline $\begin{array}{l}\text { 1WT@PT_Late@0 } \\
\text { Stops@0 }\end{array}$ & 24 & 555 & 1.9 \\
\hline $\begin{array}{l}\text { 1WT+Sub@FT_Peak@1 } \\
\text { Stop @0 }\end{array}$ & 25 & 517 & 1.7 \\
\hline $\begin{array}{l}\text { 1WT+Sub@All Other@ } \\
\text { 1 Stop@0 }\end{array}$ & 26 & 390 & 1.3 \\
\hline $\begin{array}{l}\text { 1WT+Sub@FT_Peak@ } \\
\text { 2+ Stops@0 }\end{array}$ & 27 & 198 & 0.7 \\
\hline $\begin{array}{l}\text { 1WT+Sub@All Other } \\
@ 2+\text { Stops@0 }\end{array}$ & 28 & 139 & 0.5 \\
\hline WT2+@All@0 Stops@0 & 29 & 641 & 2.2 \\
\hline WT2+@All@1 Stop@0 & 30 & 59 & 0.2 \\
\hline WT2+@All@1 Stop@1 & 31 & 682 & 2.3 \\
\hline $\begin{array}{l}\text { WT2+@All@2+Stops } \\
@ 0\end{array}$ & 32 & 157 & 0.5 \\
\hline $\begin{array}{l}\text { WT2+@All@2+ Stops } \\
@ 1\end{array}$ & 33 & 176 & 0.6 \\
\hline \multirow[t]{2}{*}{$\begin{array}{l}\text { WT2+@All@2+ Stops } \\
@ 2+\end{array}$} & 34 & 140 & 0.5 \\
\hline & & 29,660 & \\
\hline
\end{tabular}

These groups were combined to create 5 groups as indicated in Table 6 for simplicity and to increase the significance of the groups. The highlighted groups in Table 5 were considered main work pattern group for each cluster.

Table 4 - Identified Work Pattern Groups

\begin{tabular}{|c|c|c|c|c|c|c|c|c|c|c|}
\hline & Diversions & & & & & 1 Stop & & & 2+Stops & \\
\hline & Non Work Tours & 0 & 1 & $2+$ & 0 & 1 & $2+$ & 0 & 1 & $2+$ \\
\hline \multirow{5}{*}{1 Tour } & FT_Peak & $22(54.88 \%)$ & - & - & - & - & - & - & - & - \\
\hline & FT_Early & $20(7.70 \%)$ & - & - & - & - & - & - & - & - \\
\hline & FT_Late & $21(15.31 \%)$ & - & - & - & - & - & - & - & - \\
\hline & PT_Early & $23(9.60 \%)$ & - & - & - & - & - & - & - & - \\
\hline & PT_Late & $24(1.87 \%)$ & - & - & - & - & - & - & - & - \\
\hline \multirow{3}{*}{$\begin{array}{c}\begin{array}{c}\text { 1Tourt } \\
\text { sub tours }\end{array} \\
2+\text { Tours }\end{array}$} & FT_Peak & - & - & - & $25(1.74 \%)$ & - & - & $27(0.67 \%)$ & - & - \\
\hline & All Other & - & - & - & $26(1.31 \%)$ & - & - & $28(0.47 \%)$ & - & - \\
\hline & All & $29(2.20 \%)$ & - & - & $30(0.19 \%)$ & $31(2.29 \%)$ & - & $32(0.53 \%)$ & $33(0.59 \%)$ & $34(0.47 \%)$ \\
\hline $2+$ Tours & & & \multicolumn{3}{|c|}{ Representative groups } & & & & & \\
\hline
\end{tabular}


Table 6 - Work Pattern Groups

\begin{tabular}{|l|c|c|c|}
\hline \multicolumn{1}{|c|}{ Pattern } & $\begin{array}{c}\text { Combined } \\
\text { Groups }\end{array}$ & $\begin{array}{c}\text { Group } \\
\text { ID }\end{array}$ & $\%$ \\
\hline $\begin{array}{l}\text { 1 Work Tour } \\
\text { Full time one } \\
\text { /no peak }\end{array}$ & 20,21 & 20 & 23.1 \\
\hline $\begin{array}{l}\text { 1 Work Tour } \\
\text { Full time both } \\
\text { peaks }\end{array}$ & 22 & 22 & 55.0 \\
\hline $\begin{array}{l}\text { 1 Work Tour } \\
\text { Part time }\end{array}$ & 23,24 & 23 & 11.5 \\
\hline $\begin{array}{l}\text { 1 work Tour + } \\
\text { Subtours }\end{array}$ & $25,26,27,28$ & 25 & 4.2 \\
\hline 2+ Work tours & $29-34$ & 29 & 6.3 \\
\hline
\end{tabular}

The simplified results show the following characteristics of individuals with work tour purpose.

- Majority of the members have an activity schedule of both to and from work occurring during morning and evening peak which is consistent with the expected behaviour of workers in urban areas.

- A significant number of workers try to avoid both the peak times or at least one of the peak times in their work travels.

- A significant proportion of the part time workers can be observed.

- Members with sub tours, non-work tours and multiple work tours are comparatively less.

\section{Education patterns}

All activity patterns with education purpose were grouped based on combination of following factors.

1. No. of education tours [1 tour(1ET), 1 tour + subtours $(1 \mathrm{ET}+\mathrm{Sub}), 2+$ tours $(\mathrm{ET} 2+)]$

2. No. of diversions (0 stops, 1 stop, 2+ stops)

3. No. of non-Education tours $(0,1,2+)$

4. Time categorization:

- For 1 tour

$$
\begin{aligned}
& \text { - Full Time Early (FT_Early) } \\
& \text { - Full Time Late (FT_Late) } \\
& \text { - Day_Time } \\
& \text { - Evening }
\end{aligned}
$$

- For 1 tour + subtours

- Full Time Late (FT_Late)

$$
\text { - All Other }
$$

-For 2+ tours

- All

Education patterns consist of educational tours of school students, university students, vocational and professional degree students etc. The number of educational tours categorization is similar to that of number of work tours in the work pattern groups. For example, a student who goes to school and comes back home will constitute " 1 tour" whereas a student who goes to school and comes back and later goes to a tuition class and comeback will constitute " $2+$ tours".

Definitions of diversions and non education tour categories are similar to that of contemporary work pattern categories. Time categorization is based on the time the individual departs from home and arrives back at home and how each time category is defined is indicated in Table 7. For 1 education tour a higher level of detail is given to time categories and with the addition of subtours and education tours the time categories are simplified.

\section{Table 7 - Education Pattern Time} Categorization

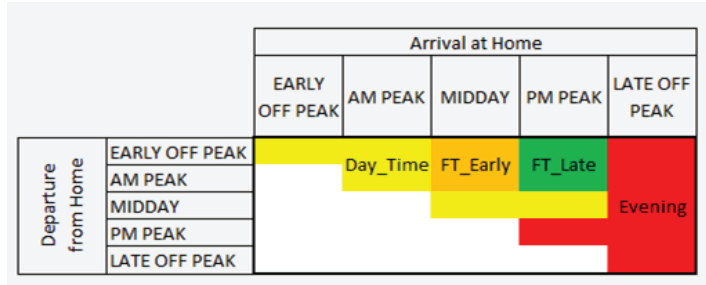

Table 8 indicates the frequencies for initially identified 13 education pattern groups. Each pattern group is identified based on "[No. of education tours] @ [Time category] @ [No. of diversions] @ [No. of non-education tours]" code.

Table 8 - Initially Identified Education Patterns

\begin{tabular}{|l|c|c|c|}
\hline \multicolumn{1}{|c|}{ Pattern Group } & ID & $\begin{array}{c}\text { In } \\
\text { Sample }\end{array}$ & $\%$ \\
\hline $\begin{array}{l}\text { 1ET@FT_Early@0 } \\
\text { Stops@0 }\end{array}$ & 1 & 22,976 & 88.3 \\
\hline $\begin{array}{l}\text { 1ET@FT_Late@0 } \\
\text { Stops@0 }\end{array}$ & 2 & 1177 & 4.5 \\
\hline $\begin{array}{l}\text { 1ET@Day_Time@0 } \\
\text { Stops@0 }\end{array}$ & 3 & 75 & 0.3 \\
\hline $\begin{array}{l}\text { 1ET@Evening@0 } \\
\text { Stops@0 }\end{array}$ & 4 & 63 & 0.2 \\
\hline $\begin{array}{l}\text { 1ET+Sub@FT_Late@1 } \\
\text { Stop@0 }\end{array}$ & 5 & 28 & 0.1 \\
\hline $\begin{array}{l}\text { 1ET+Sub@FT_Late@2+ } \\
\text { Stops@0 }\end{array}$ & 6 & 6 & 0 \\
\hline $\begin{array}{l}\text { 1ET+Sub@All Other@1 } \\
\text { Stop@0 }\end{array}$ & 7 & 567 & 2.2 \\
\hline $\begin{array}{l}\text { 1ET+Sub@All } \\
\text { Other@2+Stops@0 }\end{array}$ & 8 & 76 & 0.3 \\
\hline ET2+@All@0 Stops@0 & 9 & 19 & 0.1 \\
\hline ET2+@All@0 Stops@1 & 10 & 1 & 0 \\
\hline
\end{tabular}




\begin{tabular}{|l|c|c|c|}
\hline \multicolumn{1}{|c|}{ Pattern Group } & ID & $\begin{array}{c}\text { In } \\
\text { Sample }\end{array}$ & $\%$ \\
\hline ET2+@All@1 Stop@1 & 11 & 972 & 3.7 \\
\hline ET2+@All@2+ Stops@1 & 12 & 27 & 0.1 \\
\hline $\begin{array}{l}\text { ET2+@All@2+ } \\
\text { Stops@2+ }\end{array}$ & 13 & 21 & 0.1 \\
\hline & & 26,008 & \\
\hline
\end{tabular}

These groups were combined to create 4 groups as indicated in Table 9. The highlighted groups in Table 8 were considered the main education pattern group for each cluster.

Table 9 - Education Pattern Groups

\begin{tabular}{|l|c|c|c|}
\hline \multicolumn{1}{|c|}{ Pattern } & $\begin{array}{c}\text { Combined } \\
\text { Groups }\end{array}$ & $\begin{array}{c}\text { Group } \\
\text { ID }\end{array}$ & $\%$ \\
\hline $\begin{array}{l}\text { 1 Education } \\
\text { Tour with } \\
\text { return before } \\
\text { PM peak }\end{array}$ & 1,3 & 1 & 88.6 \\
\hline $\begin{array}{l}\text { 1 Education } \\
\text { Tour with } \\
\text { return } \\
\text { during/after } \\
\text { PM peak }\end{array}$ & 2,4 & 2 & 4.8 \\
\hline $\begin{array}{l}\text { 1 Education } \\
\text { Tour + } \\
\text { Subtour }\end{array}$ & $5,6,7,8$ & 7 & 2.6 \\
\hline $\begin{array}{l}\text { 2+ Education } \\
\text { tours }\end{array}$ & $9,10,11,12,13$ & 11 & 3.9 \\
\hline
\end{tabular}

The simplified results show the following characteristics of individuals with education tour purpose.

- Majority of the members have an activity schedule of returning from school/education institute before PM peak which is consistent with the expected schedule of school children.

- The members returning from school/education institute after PM peak of $4.8 \%$ can be attributed to students who do extracurricular activities.

- Members with multiple education tours can be attributed to students who go to tuition classes.

\section{Other Patterns}

All activity patterns that were identified as other purpose were grouped based on combination of following factors.

1. No. of tours (1 tour, 2 tours, $3+$ tours)

2. Purpose:

$$
\begin{aligned}
& \text { - Shopping (Sh) } \\
& \text { - Religious (R) } \\
& \text { - Personal (P) } \\
& \text { - Business (B) } \\
& \text { - Leisure (L) }
\end{aligned}
$$

- Other $(\mathrm{O})$

3. Time categorization:

- For 1 tour

- Peak

- Off peak

- For 2 tours

- All

-For 3+ tours

- All

Definitions of number of tour categories are similar to that of contemporary work pattern and education pattern categories.

The purpose categorization was identified using origin/destination type as in Table 10.

Table 10 - Purpose Category

\begin{tabular}{|l|l|l|}
\hline \multicolumn{2}{|c|}{ Origin/Destination type } & \multicolumn{1}{|c|}{$\begin{array}{c}\text { Assigned } \\
\text { Purpose }\end{array}$} \\
\hline 1 & Residence, dormitory & Home \\
\hline 2 & $\begin{array}{l}\text { Government, public } \\
\text { office }\end{array}$ & Personal \\
\hline 3 & $\begin{array}{l}\text { Business office, private } \\
\text { company }\end{array}$ & Personal \\
\hline 4 & Educational facility & Personal \\
\hline 5 & Religious facility & Religious \\
\hline 6 & Medical facility & Personal \\
\hline 7 & $\begin{array}{l}\text { Accommodation, } \\
\text { entertainment facility }\end{array}$ & Leisure \\
\hline 8 & Restaurant & Shopping \\
\hline 9 & Retail, traditional market & Shopping \\
\hline 10 & Supermarket & Shopping \\
\hline 11 & $\begin{array}{l}\text { Shopping mall, shopping } \\
\text { plaza }\end{array}$ & Shopping \\
\hline 12 & Grocery market & Shopping \\
\hline 13 & Factory & Personal \\
\hline 14 & $\begin{array}{l}\text { Warehouse, storage } \\
\text { facility }\end{array}$ & Business \\
\hline 15 & $\begin{array}{l}\text { Transport, } \\
\text { communication facility }\end{array}$ & Personal \\
\hline 16 & Supply, disposal facility & Business \\
\hline 17 & $\begin{array}{l}\text { Recreational, sport } \\
\text { facility }\end{array}$ & Leisure \\
\hline 18 & $\begin{array}{l}\text { Park, natural } \\
\text { environmental area etc. }\end{array}$ & Leisure \\
\hline 19 & $\begin{array}{l}\text { Agricultural, forestry and } \\
\text { fishery areas }\end{array}$ & Business \\
\hline 20 & Construction site & Business \\
\hline 21 & Other & Other \\
\hline
\end{tabular}

Time categorization is based on the time the individual departs from home and arrives back at home. For single tour a higher level of detail is given to time categories with peak time category is where either the individual's departure or return tour occurs in AM/PM peak. For multiple tours, detailed time categorization was ignored to simplify the 
process. Table 11 indicates the frequencies for initially identified 24 other pattern groups. Each pattern group is identified based on "[No. of tours] @ [Time category] @ [Purpose]" code.

Table 11 - Initially Identified other Pattern Groups

\begin{tabular}{|c|c|c|c|}
\hline Pattern Group & & $\begin{array}{c}\text { In } \\
\text { Sample }\end{array}$ & $\%$ \\
\hline 1T@Peak@R & 40 & 903 & 4.4 \\
\hline 1T@Peak@Sh & 41 & 3,361 & 16.3 \\
\hline 1T@Peak@B & 42 & 2,168 & 10.5 \\
\hline 1T@Peak@P & 43 & 5,534 & 26.9 \\
\hline 1T@Peak@L & 44 & 225 & 1.1 \\
\hline 1T@Peak@O & 45 & 773 & 3.8 \\
\hline 1T@OffPeak@R & 46 & 210 & 1 \\
\hline 1T@OffPeak@Sh & 47 & 1,886 & 9.2 \\
\hline 1T@OffPeak@B & 48 & 90 & 0.4 \\
\hline 1T@OffPeak@P & 49 & 1,988 & 9.7 \\
\hline 1T@OffPeak@L & 50 & 39 & 0.2 \\
\hline 1T@OffPeak@O & 51 & 229 & 1.1 \\
\hline 2T@All@R & 52 & 58 & 0.3 \\
\hline 2T@All@Sh & 53 & 385 & 1.9 \\
\hline 2T@All@B & 54 & 68 & 0.3 \\
\hline 2T@All@P & 55 & 2,141 & 10.4 \\
\hline 2T@All@L & 56 & 5 & 0 \\
\hline 2T@All@O & 57 & 71 & 0.3 \\
\hline 3T+@All@R & 58 & 13 & 0.1 \\
\hline 3T+@All@Sh & 59 & 37 & 0.2 \\
\hline 3T+@All@B & 60 & 11 & 0.1 \\
\hline 3T+@All@P & 61 & 362 & 1.8 \\
\hline 3T+@All@L & 62 & 4 & 0 \\
\hline 3T+@All@O & 63 & 12 & 0.1 \\
\hline & & 20,573 & \\
\hline
\end{tabular}

Table 12 - Other Pattern Groups

\begin{tabular}{|l|c|c|c|}
\hline \multicolumn{1}{|c|}{ Pattern } & $\begin{array}{c}\text { Combined } \\
\text { Groups }\end{array}$ & $\begin{array}{c}\text { Group } \\
\text { ID }\end{array}$ & $\%$ \\
\hline Single Tour - R & 40,46 & 40 & 5.4 \\
\hline $\begin{array}{l}\text { Single Tour } \\
\text { peak - Sh }\end{array}$ & 41 & 41 & 16.3 \\
\hline Single Tour - B & 42,48 & 42 & 11.0 \\
\hline $\begin{array}{l}\text { Single Tour } \\
\text { peak - P }\end{array}$ & 43 & 43 & 26.9 \\
\hline $\begin{array}{l}\text { Single Tour - L } \\
\text { and O }\end{array}$ & $44,45,50,51$ & 45 & 6.2 \\
\hline $\begin{array}{l}\text { Single Tour } \\
\text { Off peak - Sh }\end{array}$ & 47 & 47 & 9.2 \\
\hline $\begin{array}{l}\text { Single Tour } \\
\text { Off peak - P }\end{array}$ & 49 & 49 & 9.7 \\
\hline Multiple Tours & $52-63$ & 55 & 15.4 \\
\hline
\end{tabular}

These groups were combined to create 8 groups as indicated in Table 12 for simplicity and to increase the significance of the groups. The highlighted groups in Table 11 were considered main other pattern group for each cluster.
The simplified results show the following characteristics of individuals with other tour purpose.

- Most other purpose tours are single tours with $85 \%$ and multiple tours only accounting for $15 \%$.

- The other tour purpose with highest frequency is personal tours followed by shopping and business tours.

- Members with religious and leisure purpose tours are comparatively less.

- Most personal and shopping tours occur during peak times.

\subsection{Activity Pattern Distribution in Groups} For each identified activity pattern choice group, the included activity patterns were identified. The activity pattern distribution in each choice group was calculated based on the weighted number of individuals of each activity pattern.

The main activity pattern for each activity pattern choice group is shown in Table 13.

Table 13 - Main Activity Patterns

\begin{tabular}{|c|c|c|}
\hline $\begin{array}{l}\text { Pattern } \\
\text { Group }\end{array}$ & Subgroup & Main Pattern \\
\hline \multirow{5}{*}{ Work } & $\begin{array}{l}1 \text { Work Tour } \\
\text { Full time } \\
\text { both peak } \\
\text { (22) }\end{array}$ & $\mathrm{H} 2 \mathrm{~W} 4 \mathrm{H}$ \\
\hline & $\begin{array}{l}1 \text { Work Tour } \\
\text { Full time } \\
\text { one / no } \\
\text { peak (20) }\end{array}$ & $\mathrm{H} 2 \mathrm{~W} 5 \mathrm{H}$ \\
\hline & $\begin{array}{l}1 \text { Work Tour } \\
\text { Part time } \\
\text { (23) }\end{array}$ & $\mathrm{H} 2 \mathrm{~W} 3 \mathrm{H}$ \\
\hline & $\begin{array}{l}2+\text { Work } \\
\text { tours }(29)\end{array}$ & $\mathrm{H} 2 \mathrm{~W} 3 \mathrm{H} 3 \mathrm{~W} 4 \mathrm{H}$ \\
\hline & $\begin{array}{l}1 \text { work Tour } \\
+ \text { Subtours } \\
\text { (25) }\end{array}$ & $\mathrm{H} 2 \mathrm{O} 2 \mathrm{~W} 4 \mathrm{H}$ \\
\hline \multirow{4}{*}{ Education } & $\begin{array}{l}1 \text { School } \\
\text { Tour with } \\
\text { return } \\
\text { before PM } \\
\text { peak (1) }\end{array}$ & $\mathrm{H} 2 \mathrm{~S} 3 \mathrm{H}$ \\
\hline & $\begin{array}{l}1 \text { School } \\
\text { Tour with } \\
\text { return } \\
\text { during/after } \\
\text { PM peak (2) }\end{array}$ & $\mathrm{H} 2 \mathrm{~S} 4 \mathrm{H}$ \\
\hline & $\begin{array}{l}2+\text { School } \\
\text { tours (11) }\end{array}$ & $\mathrm{H} 2 \mathrm{~S} 3 \mathrm{H} 4 \mathrm{O} 4 \mathrm{H}$ \\
\hline & $\begin{array}{l}\text { 1 School } \\
\text { Tour }+\end{array}$ & $\mathrm{H} 2 \mathrm{~S} 3 \mathrm{O} 4 \mathrm{H}$ \\
\hline
\end{tabular}




\begin{tabular}{|c|l|c|}
\hline $\begin{array}{c}\text { Pattern } \\
\text { Group }\end{array}$ & Subgroup & Main Pattern \\
\hline & Subtour (7) & \\
\hline \multirow{5}{*}{} & $\begin{array}{l}\text { Single Tour } \\
\text { peak - P (43) }\end{array}$ & H2O3H@P \\
\cline { 2 - 3 } & $\begin{array}{l}\text { Single Tour } \\
\text { peak - Sh } \\
(41)\end{array}$ & H2O3H@Sh \\
\cline { 2 - 3 } & $\begin{array}{l}\text { Multiple } \\
\text { Tours (55) }\end{array}$ & H2O2H3O3H@P \\
\cline { 2 - 3 } & $\begin{array}{l}\text { Single Tour } \\
- \text { B (42) }\end{array}$ & H2O4H@B \\
\cline { 2 - 3 } & $\begin{array}{l}\text { Single Tour } \\
\text { Off peak - P } \\
(49)\end{array}$ & H3O3H@P \\
\cline { 2 - 3 } & $\begin{array}{l}\text { Single Tour } \\
\text { off-peak - Sh } \\
(47)\end{array}$ & H3O3H@Sh \\
\cline { 2 - 3 } & $\begin{array}{l}\text { Single Tour } \\
- \text { L and O } \\
(45)\end{array}$ & H2O3H@O \\
\cline { 2 - 3 } & $\begin{array}{l}\text { Single Tour } \\
- \text { R (40) }\end{array}$ & H2O3H@R \\
\hline
\end{tabular}

\section{Summary and Conclusions}

Activity based models have the ability to capture human behavioural responses in a higher resolution compared to the traditional trip based models due to their consideration of travel as a derived demand from activity participation. Activity pattern formulation is a major component in the activity-based modelling framework. It assigns a single activity pattern or probabilities of multiple activity patterns for each member that will be used for simulation in the subsequent steps in the transport demand model. The research scope is limited to creation of activity pattern groups in the activity pattern formulation component. The dataset of CoMTrans Home Visit Survey 2013 which contains details of travel activities for individuals in Western Province, Sri Lanka was used for the research.

Initially each member's activity pattern was represented using space and time dimensions. Spatial representation was restricted to home, work, education and other, and time representation consisted of 5 time periods with consideration of AM and PM peak times. The analysis revealed 1,106 unique activity patterns with education based pattern of $\mathrm{H} 2 \mathrm{~S} 3 \mathrm{H}$ and work based pattern of $\mathrm{H} 2 \mathrm{~W} 4 \mathrm{H}$ having the highest frequencies as expected. Analysis of the activity patterns based on the most prominent tour purpose revealed 3 main categories with the distribution for work tour purpose as $38.9 \%$, educational purpose as $34.1 \%$ and other purposes as $27 \%$.

These 3 categories were further categorized based on number of purpose and non-purpose tours, diversions and time category in the case of educational and work patterns and number of tours, purpose and time category for other pattern category. 17 subgroups were identified which consisted of 5 work pattern groups, 4 educational pattern groups and 8 other pattern groups. The activity pattern distribution in each subgroup was also derived.

Frequency distribution of the subgroups displays behaviours that are relevant for each tour purpose. Analysis of work purpose subgroups indicates that majority of workers have both to work and from work trips during peak times. The distribution also shows that a significant number of members try to at least avoid peak times at least in one of the legs of the tour. The education purpose subgroup frequencies display the behavioural aspect of majority of members having an activity schedule of returning from school/education institute before PM peak in line with school/educational institute durations. Further, the students who engaged in extracurricular activities after school/educational institute hours, were captured through activity schedules with return leg during PM peak. The other purpose subgroup frequencies indicate that majority of members prefer a single tour compared to multiple tours. The most frequent single other purpose tours were for personal and shopping purposes.

Developing a choice model for the derived subgroups based on socio economic characteristics can be considered as future scope of the research.

\section{Acknowledgement}

The funding provided through Senate Research Committee grant (SRC/LT/2020/22) and other facilities for the research provided by University of Moratuwa is gratefully acknowledged by the authors. 


\section{References}

1. Ettema, D. (1996). "Activity-Based Travel Demand Modeling". Unpublished Ph.D. dissertation, Faculteit Bouwkunde, Technische Universiteit Eindhoven, 297 p.

2. ATAP (2016). “Australian Transport Assessment and Planning Guidelines", (ATAP): T1 Travel Demand Modelling.

3. Castiglione, J., Bradley, M., and Gliebe, J. (2015). "Activity-Based Travel Demand Models: A Primer." Transportation Research Board. Washington, D.C.

4. Pas, E. I., (1983). "A Flexible and Integrated Methodology for Analytical Classification of Daily Travel-Activity Behavior", Transportation Science, 17(4), pp. 365-477.

5. Recker, Wilfred W., (1983). Chaining behavior in urban trip making (Vol. 1), Institute of Transportation Studies, University of California, Irvine.

6. Vaughn, K. M., Speckman, P., \& Pas, E. I. (1997). "Generating Household Activity-Travel Patterns (HATPs) for Synthetic Populations", Annual Transportation Research Board Meeting, Washington, DC.

7. Pas, E. (1998). Time in Travel Choice Modeling pp. 231-250.
8. ULTRANS, \& HBA Specto Incorporated. (2011). CSTDM09- Model Development-Travel Behavior Datasets.

9. Galgamuwa, U., Perera, L., \& Bandara, S. (2016). "Development of a Driving Cycle for Colombo, Sri Lanka: An Economical Approach for Developing Countries", Journal of Advanced Transportation, 50(7), 1520-1530.

10. Hafezi, M. H., Liu, L., \& Millward, H. (2019). “A Time-Use Activity-Pattern Recognition Model for Activity-Based Travel Demand Modeling", Transportation, 46(4), 1369-1394.

11. De Silva, D. (2011). An Analysis of Daily Activity Patterns in Time and Space, Doctoral dissertation, University of Calgary.

12. Ding, G., (2009). Deriving Activity Patterns from Individual Travel Diary Data: A Spatiotemporal Data Mining Approach, Doctoral dissertation, The Ohio State University.

13. JICA, (2014). Urban Transport System Development Project for Colombo Metropolitan Region and Suburbs-Technical Report no. 3.

14. Department of Census and Statistics, (2015). Census of Population and Housing 2012- Sri LankaPopulation Tables.

15. Transportation Research Board \& Institute of Medicine, (2005). Does the Built Environment Influence Physical Activity?: Examining the Evidence - Special Report 282. 